\title{
EVALUATION OF COOPERATIVE LEARNING: DOES IT ENHANCE LEARNING AMONG THE GEN Z LEARNERS?
}

\author{
Teh Ya Yee ${ }^{1 *}$ and Moy Tow Yoon ${ }^{1}$ \\ ${ }^{1}$ Sunway College, Malaysia
}

\begin{abstract}
Cooperative learning has long been introduced in classroom teaching due to its ability to capitalise on students' academic and social learning experiences. Having identified the different learning styles and needs of the current student who are the Generation Z (Gen Z) in our classroom, it is crucial to address the question of how applicable is cooperative learning in promoting interactive and effective learning for more rewarding learning experience. This action research attempts to understand the students' perceptions towards the three cooperative learning strategies they have experienced with the objective to identify the best strategy to enhance the students' learning experiences. The study population of this action research is the second and third year undergraduates of a compulsory subject. A descriptive research design using a structured questionnaire was used and cooperative learning was found to be an effective approach in enriching the learning experience among the Gen $\mathrm{Z}$ learners.
\end{abstract}

Keywords: Cooperative learning, Generation Z learners

\section{Introduction}

This action research seeks to understand the students' perceptions towards the cooperative learning activities they have experienced in the classroom. Three cooperative learning activities were carried out in the Entrepreneurial Skills class. This class is classified as a non-core, general studies subject undertaken by the second and third year students of an Australian twinning programme in a private college in Kuala Lumpur, Malaysia. Under the Malaysia Private Higher Education Act 1996, students studying in a Malaysian private institute are required to pass five general studies subjects as a pre-requisite for the award of their degrees. The grades of the general studies subjects are however, not recorded in the students' academic transcripts but on a separate document.

Although the general studies subjects are designed to provide valuable knowledge and information, most students perceive them negatively and would put in minimum effort to just achieve a pass grade. They lack motivation to attend classes. Even if they were present in the class physically, their attention was often not with the on-going lesson. This proved to be a big challenge to achieve the desired learning outcomes.

To encourage learning and classroom engagement, three different cooperative learning strategies, namely, Group Investigation (GI), Teams-Games-Tournaments (TGT) and Co op-Co op were used. This learning approach was carried out over a series of lessons in the Entrepreneurial Skills (ES) class to promote a more interactive and effective class for more rewarding learning outcomes.

\section{Cooperative Learning}

Cooperative learning has garnered a huge interest in classroom teaching since decades ago due to its ability to capitalise on students' academic and social learning experiences. Cooperative learning is beyond simply work together as a team to complete a task. Students are required to work together in groups that are carefully designed to promote positive interdependence and individual accountability (Davison \& Major, 2014). 
Cooperative learning advocates have recommended a range of strategies to ensure students learn and work together. Examples of the cooperative learning strategies are Think-Pair-Share, Jigsaw, Group Investigation, Teams-Games-Tournaments and Co op-Co op.

Unlike active learning which requires students "to do", cooperative learning requires students "to do with others" (Machemer \& Crawford, 2007). Students are therefore responsible for both their individual and group learning. They share ideas and resources, and plan cooperatively on what and how to study (Sharan \& Sharan, 1987).

According to Johnson, Johnson and Smith (1998), there are five elements of cooperative learning: positive interdependence, face-to-face interaction, individual accountability, social skills, and group processing. These elements are necessary to construct effective cooperative learning experiences. Therefore, extensive face-to-face communications by engaging students in real discussion are required in the learning process.

Although Abu and Flower (1997) reported no significant difference in the achievement, retention, and attitude of students in cooperative learning classroom, Panitz (2003) found cooperative learning helped to improve student motivation and allow them to participate in a classroom atmosphere and enjoy important social learning experience. This is supported by Ajaja and Eravwoke (2010) who said that cooperative learning helped students to develop positive attitudes toward learning. Fu (2013) concluded that cooperative learning has positive effects on improving the passive classroom but also highlighted that there should be flexibility to cater to different individual learning style.

\section{Generation Z}

The Generational Theory developed by Strauss and Howe (1991) suggests to categorise different cohorts based on the birth year due to different set of historical events and related phenomena that creates a distinct gap among the generations (Parry \& Urwin, 2011). Succeeding the Veterans, Baby boomers and Generation X, the fourth generation, which was identified as Generation Y (Gen Y) received vast attentions from the researchers in the last decade. Born between 1982 and 2000, the Gen Y was also known as the Millennials (Howe \& Strauss, 2000). Their unique and distinct characteristics were widely studied and discussed in the education and industries across the globe (Desai \& Lele, 2017).

The rising generation which is identified as the Generation $\mathrm{Z}$ (Gen $\mathrm{Z}$ ) has entered college and has replaced the Gen Y. Gen Z was born between mid-1990s to early 2010s (Cameron \& Pagnattaro, 2017; Rothman, 2014; William, 2015). This generation has earned the nickname of Digital Natives, iGen and Screensters (Rothman, 2014). These nicknames were given because they were born and brought up in a connected world and digital devices were widely accessible to them since young. This generation is unable to imagine their lives without internet and smartphone. They are the first real global generation and high-tech is in their blood (Andrea, Gabriella \& Tima, 2016).

Gen $\mathrm{Z}$ has very short attention span. Their brains are wired to complex visual images since young. They are easily bored and ready to move to the next thing. Gen $\mathrm{Z}$ cannot focus and analyse complex information for an extended period (Rothman, 2014; Shatto \& Erwin, 2016). From the positive perspective, they are the "highly evolved eight-second filters", who can quickly sort through and assess enormous amounts of information (Cameron \& Pagnattaro, 2017). The exceptionally short attention span of Gen $\mathrm{Z}$ poses tremendous challenges in the classroom, especially when the traditional lecture-based is used in teaching.

Seemiller and Grace (2017) found that although Gen Z prefers independent learning, they prefer working in group too. This is supported by evidence that Gen $\mathrm{Z}$ likes collaboration and prefers conversation (Thacker, 2016; Desai \& Lele, 2017). However, there are also contradicting findings which claim that Gen $\mathrm{Z}$ is the digital 
native who prefers using social media over direct contact with people (Rothman, 2016) and lack face-to-face communication skills, which result in socially disinterested behaviours (Turner, 2015).

\section{Purpose of the Study}

This study is conducted to understand the students' perceptions towards the three cooperative learning strategies they have experienced in order to evaluate the applicability of cooperative learning in promoting interactive and effective learning. Recognising the changing characteristics of students who are now the Gen $\mathrm{Z}$, the specific objectives of this study are:

- To evaluate the design of cooperative learning activities.

- To understand the perceptions of students from the perspective of a team member toward the use of Teams-Games-Tournaments, Group Investigation and Co op-Co op.

- To understand the perceptions of students from an individual's perspective toward the use of Teams-Games-Tournaments, Group Investigation and Co op-Co op.

- To compare the effectiveness of Teams-Games-Tournaments, Group Investigation and Co op-Co op in enhancing learning and promoting class interaction.

We hypothesise that:

H1: There exists some differences in the distributions of attributes corresponding to Teams-GamesTournaments, Group Investigation and Co op-Co op.

H2: The demotivation reasons to undertake a subject and the design of activity to enhance learning are associated.

H3: The demotivation reasons to undertake a subject and the design of activity to encourage group discussion are associated.

\section{Methodology}

A quantitative survey using a structured questionnaire was conducted in December, 2017 with students enrolled in the Entrepreneurial Skills subject. The survey was conducted in three stages to evaluate three different cooperative learning strategies used in the subject, namely Teams-Games-Tournaments (TGT), Group Investigation (GI) and Co op-Co op. About $65 \%$ out of 67 students who enrolled in the subject participated in the survey. Due to timing and logistical issues, student participation was less than expected. The questionnaire was administered by the subject lecturer during classes. This method enabled the students to seek clarification from the lecturer when needed as they responded to the questionnaires.

The questionnaire consisted of four main sections. Ten items related to various aspects of the design of the activities were devised to evaluate the activities in Section A. Section B focused on the respondents' perceptions on the group members they worked with while Section $\mathrm{C}$ required the respondents to examine their own perceptions with regard to the learning strategies. Eight plausible reasons which are related to the students' motivation or lack of motivation to study the subject Entrepreneurial Skills were investigated in Section D. We searched extensively for published scales to measure the constructs set in our objectives but was unsuccessful. As a result, we chose to develop our own scales based on our readings and experience. The items in the four sections were measured using a 5-point Likert scale where 1=Strongly disagree, 2=Disagree, 3=Neutral, 4=Agree and 5=Strongly agree. 


\section{Results and Conclusions}

The survey was carried out in three stages to evaluate three cooperative learning strategies. 41 out of 67 students (61\%) participated in the TGT survey, 50 (75\%) took part in the GI survey and only 39 out of 67 (58\%) completed the Co op-Co op survey. $90 \%$ of the participants are in the Gen-Z age bracket between 18 to 23 years old. $40 \%$ of respondents are males and $84 \%$ are Malaysian.

\section{Design of activities}

To ensure students would attend the Entrepreneurial Skills classes, activities were designed to create an active learning environment in the classroom. Learning Gen Z's characteristics leads us to understand that traditional lecture-tutorial approach is not likely to be effectively. Different teaching techniques should be adapted to create an engaging learning environment (Thacker, 2016). Therefore, different cooperative learning strategies were used to motivate students to participate in class activities and enhance their understanding of the subject matter. The findings are presented in Table 1.

Overall, the students rated the activities positively. Positive items generated means above 3.00. The activities achieved the goals in encouraging group discussion with a relatively high mean of $3.79 .70 .8 \%$ of respondents agreed with this item. $64.6 \%$ of the respondents affirmed that the design of the activities helped them to learn better (mean=3.63). Majority of the respondents also agreed that the activities were well-planned, helped to retain their knowledge and fun.

Table 1: Evaluation of the Design of Cooperative Learning activities - Summary Statistics

\begin{tabular}{|c|c|c|c|c|c|}
\hline Item & Mean & $\begin{array}{l}\text { Std. } \\
\text { Error }\end{array}$ & $\begin{array}{l}\text { Generally } \\
\text { disagree }(\%)\end{array}$ & $\begin{array}{l}\text { Neutral } \\
(\%)\end{array}$ & $\begin{array}{l}\text { Generally } \\
\text { agree }(\%)\end{array}$ \\
\hline $\begin{array}{l}\text { The design of the activity encourages group } \\
\text { discussion }\end{array}$ & 3.79 & .086 & 10.8 & 18.5 & 70.8 \\
\hline $\begin{array}{l}\text { The design of the activity helps me to learn } \\
\text { better }\end{array}$ & 3.63 & .082 & 10.8 & 24.6 & 64.6 \\
\hline The design of the activity is well-planned & 3.57 & .077 & 9.2 & 32.3 & 58.5 \\
\hline $\begin{array}{l}\text { The group activity helps to retain my } \\
\text { knowledge }\end{array}$ & 3.56 & .076 & 9.2 & 30.0 & 60.8 \\
\hline The group activity is fun & 3.45 & .093 & 16.9 & 29.2 & 53.8 \\
\hline $\begin{array}{l}\text { There is too little time given to complete the } \\
\text { activity }\end{array}$ & 3.18 & .089 & 23.8 & 40.0 & 36.2 \\
\hline $\begin{array}{l}\text { The activity increases my understanding on } \\
\text { the subject }\end{array}$ & 3.08 & .102 & 29.2 & 30.8 & 40.0 \\
\hline The design of the activity is boring & 2.54 & .094 & 50.0 & 33.8 & 16.2 \\
\hline $\begin{array}{l}\text { The instruction for the group activity is not } \\
\text { clear }\end{array}$ & 2.35 & .080 & 59.2 & 32.3 & 8.5 \\
\hline The activity is a waste of time & 2.27 & .082 & 65.4 & 26.2 & 8.5 \\
\hline
\end{tabular}

Implementation of cooperative learning activities required substantial time in the classroom as reflected by the findings. $36.2 \%$ agreed or strongly agreed that there was too little time given to complete the activities, while $40 \%$ of them took the neutral view.

Only small proportions of respondents agreed or strongly agreed with the negative items. Instead, majority found the activities not boring, instructions were clear and not a waste of time. 


\section{Group Perceptions}

To understand the students' perceptions towards working in group, a multi-item scale which encompassed a wide range of both positive and negative issues was developed. Exploratory factor analysis was used to identify possible factor structure and reliability analysis was conducted to evaluate the reliability of the scale. The results are summarised in Table 2.

The principal components extraction method with varimax rotation using Kaiser Normalization were used to determine the factor structure of the scale. Two components or factors with eigenvalues greater than 1.00 were extracted, providing a total explanation of initial variance for up to 56.9\%. The explained variance was relatively high with well-defined factor structure. Kaiser-Meyer-Olkin measure obtained was 0.860, higher than the accepted level of 0.6 .

The two factors were named as Benefit and Drawback. Both the factors were subjected to reliability test and the results were satisfactory. The Cronbach's alpha achieved was 0.800 for Benefit and 0.791 for Drawback, indicating high internal consistency.

Table 2: Summary of factor analysis and reliability analysis results

\begin{tabular}{lll}
\hline Factor & Item & Cronbach's \\
& The group activity enhances good working relationships among students. \\
\hline & The group activity helps me to socialize more. & 0.800 \\
Benefit & The group activity improves my attitude towards learning. & \\
& The group activity increases participation in class. & \\
& There is good interaction among groupmates during the activity. & 0.791 \\
& (Not) All my groupmates participate during the group discussion & \\
Drawback & I do not learn from my groupmates. & \\
& My groupmates pull down my marks. \\
& The discussion during group activity is not effective. \\
& Too much time is spent in understanding other groupmates opinion.
\end{tabular}

The eleven items were also ranked using the mean scores. Detailed information of the distribution of the data were analysed and summarised by recoding the 5-point Likert scale to 3 categories, namely Generally disagree, Neutral and Generally agree. The results are summarised in Table 3.

Table 3: Group Perceptions Summary Statistics

\begin{tabular}{|c|c|c|c|c|c|}
\hline Item & Mean & $\begin{array}{l}\text { Std. } \\
\text { Error }\end{array}$ & $\begin{array}{l}\text { Generally } \\
\text { disagree } \\
(\%)\end{array}$ & $\begin{array}{l}\text { Neutral } \\
(\%)\end{array}$ & $\begin{array}{l}\text { Generally } \\
\text { agree }(\%)\end{array}$ \\
\hline $\begin{array}{l}\text { The group activity enhances good working relationships } \\
\text { among students. }\end{array}$ & 3.78 & .073 & 5.4 & 26.9 & 67.7 \\
\hline $\begin{array}{l}\text { All my groupmates participate during the group } \\
\text { discussion }\end{array}$ & 3.78 & .076 & 6.2 & 27.7 & 66.2 \\
\hline It is fun to work with students who are different from me. & 3.76 & .073 & 7.7 & 26.2 & 66.2 \\
\hline The group activity helps me to socialize more. & 3.71 & .075 & 8.5 & 23.1 & 68.5 \\
\hline $\begin{array}{l}\text { The group activity improves my attitude towards } \\
\text { learning. }\end{array}$ & 3.64 & .076 & 8.5 & 25.4 & 66.2 \\
\hline There is good interaction among groupmates during the & 3.61 & .078 & 10.0 & 30.0 & 60.0 \\
\hline
\end{tabular}




\begin{tabular}{llllll}
\hline activity. & & & & \\
\hline The group activity increases participation in class. & 3.21 & .101 & 26.2 & 27.7 & 46.2 \\
\hline $\begin{array}{l}\text { Too much time is spent in understanding other } \\
\text { groupmates opinion. }\end{array}$ & 2.75 & .090 & 40.0 & 36.9 & 23.1 \\
$\begin{array}{l}\text { The discussion during group activity is not effective. } \\
\text { I do not learn from my groupmates. }\end{array}$ & 2.63 & .089 & 48.5 & 31.5 & 20.0 \\
\hline My groupmates pull down my marks. & 2.50 & .080 & 51.5 & 35.4 & 13.1 \\
\hline Note: Generally disagree = Strongly disagree + Disagree, Generally agree = Strongly agree + Agree & 2.29 & .084 & 62.3 & 27.7 & 10.1 \\
\hline
\end{tabular}

Table 3 shows that respondents were happy to learn in a group setting. Top on their ranking list is that group activities enhanced good working relationships among them with a mean of 3.78 in a 5-point Likert scale. $67.7 \%$ of them agreed or strongly agreed with this benefit. They also ranked the statement 'All my groupmates participate during the group discussion' very close to this benefit. Furthermore, students found working with others who were different from them to be fun, helped them to socialize, improved their attitudes toward learning, encouraged good interaction, increased participation in the class. All these attributes are vital as a holistic educational approach to prepare the students for their well-being in general and to meet their future workplace requirements work place in particular (Andrea, Garbiella \& Timea, 2016).

It is worth noting that this study revealed that majority of respondents disagreed or strongly disagreed that their groupmates pulled down their marks $(62.3 \%)$ and they did not learn from their group mates $(51.5 \%)$.

Overall, the students reported positive learning experience as a team member in a group using cooperative learning activities, despite the fact that the subject is not a subject of their choice but a compulsory subject they have to undertake to fulfil the requirement of the Malaysian Higher Education Ministry.

\section{Individual Perceptions}

The students' perceptions towards cooperative learnings as an individual were evaluated using a 10-item scale. Exploratory factor analysis was conducted using the principal components extraction method and no violation of assumptions were detected. Two factors were identified and named as 'Synergism' and 'Dislike'. Reliability tests yielded Cronbach's alpha values of 0.798 for Synergism and 0.687 for Dislike, both are above 0.6 and indicate good internal consistency. The results are summarised in Table 4.

Table 4: Summary of factor analysis and reliability analysis results

\begin{tabular}{llc}
\hline & & Cronbach's \\
Factor & Item & Alpha \\
\hline Synergism & I learn more in group activity than when I work alone. & 0.798 \\
& I am engaged throughout the activity. \\
& I am excited to participate in the activity. & \\
& I am more active when I work in group. \\
& My attitude towards learning improved during group activity. & 0.687 \\
\hline Dislike & I am frustrated when my groupmates are not focused during discussion. & \\
& I do not like to participate during group activity & \\
& I can perform better when I work alone. & I do not like the group activity. \\
& I feel bored during the activity.
\end{tabular}

To understand the individual respondent's perception about themselves in the cooperative learning classroom, the 10 items are analysed and ranked in descending order of the means. The results are summarised in Table 5. 
It can be observed from Table 5 that majority $(63.1 \%)$ of the students reported they were engaged throughout the activities. $52.3 \%$ felt they were more active and $54.6 \%$ reported they learned more in group activities than when working alone. They were also positive that their attitudes improved and were excited to participate in their activities. The positive perceptions created more synergy in the classroom and enhance effective learning.

Table 5: Individual Perceptions Summary Statistics

\begin{tabular}{|c|c|c|c|c|c|}
\hline Item & Mean & $\begin{array}{l}\text { Std. } \\
\text { Error }\end{array}$ & $\begin{array}{l}\text { Generally } \\
\text { disagree } \\
(\%)\end{array}$ & $\begin{array}{l}\text { Neutral } \\
(\%)\end{array}$ & $\begin{array}{l}\text { Generally } \\
\text { agree }(\%)\end{array}$ \\
\hline I am engaged throughout the activity. & 3.65 & .078 & 9.2 & 27.7 & 63.1 \\
\hline I am more active when I work in group. & 3.48 & .073 & 11.5 & 36.2 & 52.3 \\
\hline I learn more in group activity than when I work alone. & 3.46 & .089 & 16.9 & 28.5 & 54.6 \\
\hline $\begin{array}{l}\text { My attitude towards learning improved during group } \\
\text { activity. }\end{array}$ & 3.45 & .069 & 7.7 & 46.2 & 46.2 \\
\hline I am excited to participate in the activity. & 3.35 & .089 & 17.7 & 37.7 & 44.6 \\
\hline $\begin{array}{l}\text { I am frustrated when my groupmates are not focused } \\
\text { during discussion. }\end{array}$ & 2.95 & .084 & 33.8 & 38.5 & 27.7 \\
\hline I can perform better when I work alone. & 2.87 & .093 & 37.7 & 35.4 & 26.9 \\
\hline I feel bored during the activity. & 2.56 & .094 & 52.3 & 29.2 & 18.5 \\
\hline I do not like the group activity. & 2.52 & .085 & 51.5 & 35.4 & 13.1 \\
\hline I do not like to participate during group activity & 2.30 & .076 & 63.1 & 29.2 & 7.7 \\
\hline
\end{tabular}

On the other hand, negatively worded items recorded lower mean than the average of 3.00, indicating respondents did not agree with these items. Specifically, 63.1\% disagreed or strongly disagreed with the statement they did not like to participate during group activities, 51.5\% generally disagreed that they did not like the group activities and majority $(52.3 \%)$ reported they did not feel bored during the activities.

It can be concluded that results from Table 5 support the premise that cooperative learning strategies enhance synergism and improve learning in our case study.

\section{Differences of Perceptions among Cooperative Learning strategies}

In order to determine if the three cooperative strategies used in this case study were perceived differently, the four factors extracted, which are the attributes of each strategy, were compared across the three learning strategies, namely Teams-Games-Tournament (TGT), Group Investigation (GI) and Co op-Co op. Average linear composite of the factors for each strategy were computed to preserve the interpretability of the scale where 1 represents strongly disagree and 5 represents strongly agree. Tests of normality using Shapiro-Wilk test showed that most of the factors are not normal. Hence non-parametric test was used to compare the factors or attributes (Benefit, Drawback, Synergism and Dislike). Mann Whitney tests based on mean ranks were used to compare the distributions of the four factors by pairs of learning strategies used as summarised in $\mathrm{H} 1$.

H1: There exists some differences in the distributions of attributes corresponding to Teams-GamesTournament, Group Investigation and Co op-Co op

The test results are presented in Table 6. Only two pairs were found to have significantly different distributions at the 5\% significance level. Firstly, distributions of Benefit for the pair TGT and GI. The p-value of the test is 0.004, lower than 0.05. Mean rank of GI (53.06) is significantly higher than that of TGT (37.39). The finding suggests that the respondents found GI to be more beneficial than TGT. The second significant difference was 
found in Synergism between the pair TGT and Co op-Co op. TGT was perceived as better ( $\operatorname{mean}$ rank $=46.73$ ) than Co op-Co op (mean rank $=33.95$ ) in enhancing synergism.

Table 6: Mann Whitney Tests Results

\begin{tabular}{|c|c|c|c|c|}
\hline \multirow[b]{2}{*}{ Strategies } & \multicolumn{4}{|c|}{ Mean Rank } \\
\hline & Benefit & Drawback & Synergism & Dislike \\
\hline TGT $(n=41)$ & 37.79 & 44.35 & 49.17 & 43.27 \\
\hline GI $(n=50)$ & 53.06 & 47.35 & 43.40 & 48.24 \\
\hline $\mathrm{p}$-value & $0.004 *$ & 0.589 & 0.297 & 0.368 \\
\hline TGT $(\mathrm{n}=41)$ & 38.89 & 39.89 & 46.73 & 37.50 \\
\hline Co op-Co op $(n=39)$ & 42.19 & 41.14 & 33.95 & 43.65 \\
\hline p-value & 0.523 & 0.809 & $0.013 *$ & 0.234 \\
\hline GI $(n=50)$ & 48.59 & 45.82 & 48.98 & 44.27 \\
\hline Co op-Co op $(n=39)$ & 40.40 & 43.95 & 39.90 & 45.94 \\
\hline p-value & 0.133 & 0.733 & 0.098 & 0.762 \\
\hline
\end{tabular}

*Significant at the 0.05 level of significance

\section{What are the reasons students were not motivated to study Entrepreneurial Skills?}

Entrepreneurial Skills is not an academic subject in the business degree programme undertaken by our study population. Due to the unique situation that it is taught to fulfil the Malaysian Higher Education Ministry's requirement, not many students are motivated to study the subject.

Our study found that 'It is a compulsory subject' is the most agreed reason that students were not motivated to study Entrepreneurial Skills, followed by 'I am forced to take this subject' and 'I do not like the content of the subject'. The reasons cited for the lack of motivation are summarized in Table 7.

\section{Are Lack of Motivation and Design of Activities related?}

The lack of motivation to study a subject could often lead to negative perceptions of the design of activities in subject delivery. To investigate the relationships of the eight reasons investigated and the students' perceptions toward the statement 'The design of the activity helps me to learn better', Chi-square test of independence and cross-tabulation of the pairs of variables were conducted to test H2. Similarly, H3 was tested to uncover possible relationships between the demotivation reasons and the statement 'The design of the activity encourages group discussion'.

$\mathrm{H} 2$ : The demotivation reasons to undertake a subject and the design of activity to enhance learning are associated

H3: The demotivation reasons to undertake a subject and the design of activity to encourage group discussion are associated 
Table 7: Reasons not motivated to study Entrepreneurial Skills

\begin{tabular}{llllll}
\hline Item & Mean & $\begin{array}{l}\text { Std. } \\
\text { Error }\end{array}$ & $\begin{array}{l}\text { Generally } \\
\text { disagree }(\%)\end{array}$ & $\begin{array}{l}\text { Neutral } \\
(\%)\end{array}$ & $\begin{array}{l}\text { Generally } \\
\text { agree }(\%)\end{array}$ \\
\hline It is a compulsory subject. & 3.56 & .094 & 16.9 & 28.5 & 54.6 \\
\hline I am forced to take this subject. & 3.38 & .099 & 24.6 & 30.8 & 44.6 \\
\hline I do like the content of this subject. & 3.05 & .089 & 30.8 & 36.9 & 32.3 \\
\hline The subject is taking too much of my time. & 3.02 & .094 & 33.8 & 34.6 & 31.5 \\
\hline I am not interested in this subject. & 2.84 & .090 & 40.0 & 36.9 & 23.1 \\
\hline I do not like the design of the assessments. & 2.65 & .082 & 43.8 & 41.5 & 14.6 \\
\hline I do not like the way the class is conducted. & 2.62 & .078 & 42.3 & 46.9 & 10.8 \\
\hline $\begin{array}{l}\text { I do not see the relevance of it in my future } \\
\text { career. }\end{array}$ & 2.42 & .086 & 56.2 & 33.8 & 10.2 \\
\hline
\end{tabular}

Note: Generally disagree $=$ Strongly disagree + Disagree, Generally agree $=$ Strongly agree + Agree

The test results of $\mathrm{H} 2$ and $\mathrm{H} 3$ are summarised in Table 8. Four out of eight tests represented by $\mathrm{H} 2$ and $\mathrm{H} 3$ respectively have significant relationships between the demotivation reasons and the statement regarding enhancing learning or group discussion. Analysis of the cross-tabulation tables revealed the general trend that the higher their disagreement level with the reasons they were demotivated, the more they agreed that the design of the activity helped them to learn better. These implied that when students were not demotivated by these reasons, they appreciated the design of activities better.

Table 8: Summary of Chi-square tests

\begin{tabular}{lll}
\hline Demotivating reason & $\mathrm{H}_{2}$ (p-value) & $\mathrm{H}_{3}$ (p-value) \\
\hline It is a compulsory subject. & 0.188 & 0.265 \\
\hline I am forced to take this subject. & 0.098 & 0.104 \\
\hline I do like the content of this subject. & 0.083 & $0.008^{*}$ \\
\hline The subject is taking too much of my time. & $0.032^{*}$ & 0.837 \\
\hline I am not interested in this subject. & 0.123 & 0.264 \\
\hline I do not like the design of the assessments. & $0.000^{*}$ & $0.001 *$ \\
\hline I do not like the way the class is conducted. & $0.015^{*}$ & $0.021 *$ \\
\hline I do not see the relevance of it in my future career. & $0.001 *$ & $0.012^{*}$ \\
\hline *Significant at the 0.05 level of significance & &
\end{tabular}

Interestingly, although 'It is a compulsory subject' and 'I am forced to take this subject' were ranked as the top two demotivating reasons by students who took the Entrepreneurial Skills subject, their Chi-square tests with both the statements 'The design of the activity helps me to learn better' and 'The design of the activity encourages group discussion' were not significant. Cross-tabulation analysis results of these variables show that irrespective of their level of agreement with the demotivation reasons, majority of them said that the design of the cooperative learnings help them to learn better and encouraged their group participation. These findings are strong evidence that using cooperative learning strategies in teaching a subject which student would rather avoid have proven to be successful.

\section{Conclusions and Implications}

The results of this case study point to favourable acceptance of cooperative learning strategies by the Gen-Z students. Positive learning experiences were reported from both the group and individual perspectives. The case study provided strong evidence that using cooperative learning strategies creatively helped the students to learn 
better and encouraged group participation even when the subject taught is ranked highly demotivating because it is a compulsory subject being forced on the students. The Gen-Z students has shorter attention span, cannot concentrate or focus on long lecture nor complex information. Besides, they prefer visual form of learning such as picture and videos. To expect them to attend traditional lecture and tutorial dutifully is a big challenge. What more when the subject is considered as unimportant or being forced on them, like in this case study.

There is no evidence that a particular strategy is more superior. While Group Investigation(GI) is ranked better than Teams-Games-Tournament (TGT) in generating benefits such as enhancing good working relationships among students, TGT is perceived to create more synergism such as excitement than Co op-Co op. Instead, we learned from this study that the choice of strategies depends on many factors. One has to be clear of the objective of a particular activity before a strategy is chosen to maximise its benefits. Giving the students sufficient time to be familiar with a particular strategy is also vital. Otherwise some students may not be able to follow the instruction and become frustrated while the faster learner will feel a lot of time is wasted while waiting for others to response. To overcome this set back, our next cooperative learning class will be using two instead of three cooperative learning strategies. Hopefully students will gain more academic and social learning experiences with implementation of findings from this case study.

\section{References}

Abu, R. B., and Flowers, J., 1997, The effects of cooperative learning methods on achievement, retention, and attitudes of home economics students in North Carolina. Journal of Career and Technical Education, 13(2).

Ajaja, O. P., and Eravwoke, O. U., 2010, Effects of cooperative learning strategy on junior secondary school students achievement in integrated science. Electronic Journal of Science Education, 14(1), 1-18.

Andrea, B., Gabriella, H., and Tímea, J., 2016, Y and Z Generations at workplaces. Journal Of Competitiveness, 8(3), 90-106.

Cameron, E. A., and Pagnattaro, M. A., 2017, Beyond Millennials: engaging Generation Z in business law classes. Journal of Legal Studies Education, 34(2), 317-324.

Davidson, N., and Major, C., 2014, Boundary crossings: Collaborative learning, cooperative learning, and problem-based learning. Journal on Excellence in College Teaching, 25(3\&4), 7-56.

Desai, S. P., \& Lele, V., 2017, Correlating Internet, social networks and workplace - a case of Generation Z students. Journal Of Commerce \& Management Thought, 8(4), 802-815.

Fu, X., 2013, An Action Research Report on Applying Co-Operative Learning Techniques in an Intensive English Reading Class in China. English Language Teaching, 6(10), 17-31.

Gomleksiz, M. N., 2007, Effectiveness of cooperative learning (Jigsaw II) method in teaching English as foreign language to engineering students (Case of Firat University, Turkey). European Journal of Engineering Education, 32(5), 613-625.

Hampton, D. C., and Keys, Y., 2016, Generation Z students: Will they change our nursing classrooms? Journal of Nursing Education and Practice, 7(4), 111-115.

Howe, N., and Strauss, W., 2000, Millennials Rising: The Next Great Generation. New York: Vintage Books.

Johnson, D. W., Johnson, R. T., and Smith, K.A., 1998 Active learning: Cooperation in the college classroom. Edina, MN: Interaction.

Lancaster, L. C., and Stillman, D., 2004, When generations collide: how to solve the generational puzzle at work. In The Management Forum Series (pp. 1-5).

Machemer, P. L., and Crawford, P., 2007, Student perceptions of active learning in a large cross-disciplinary classroom. Active Learning in Higher Education, 8(1), 9-30.

Panitz, T., 2003, Combining writing and cooperative learning techniques in mathematics, Innovation Abstracts, XXV (4).

Parry, E., and Urwin, P., 2011, Generational differences in work values: A review of theory and evidence. International Journal of Management Reviews, 13(1), 79-96.

Rothman, D., 2014, A Tsunami of learners called Generation Z. Public Safety Online Journal, 1(1). 
Seemiller, C., and Grace, M., 2017, Generation Z: Educating and engaging the next generation of students. About Campus. 22(3), 21-26.

Sharan, Y., and Sharan, S., 1987, Training teachers for cooperative learning. Educational Leadership, 45(3), 2025 .

Shatto, B., and Erwin, K., 2016, Moving on From Millennial: Preparing for Generation Z. Journal of Continuing Education In Nursing, 47(6), 253-254.

Strauss, W., and Howe, N., 1991, Generations: The history of America's future, 1584 to 2069. New York.

Thacker, D., 2016, Preparing your sales course for Generation Z. Business Education Innovation Journal, 8(2), 198-204.

Turner, A., 2015, Generation Z: Technology and social interest. The Journal of Individual Psychology, 71(2), 103-113.

Williams, A., 2015, Move Over, Millennials: Here Comes Generation Z. The New York Times. p. 1.

Zakaria, E., Solfitri, T., Daud, Y., and Abidin, Z. Z., 2013, Effect of cooperative learning on secondary school students' mathematics achievement. Creative Education, 4(2), 98-100. 